\title{
Knowledge, Attitude and Risk Perception of Hiv/Aids among Youths in Calabar, Cross River State, Nigeria.
}

\author{
Osonwa, O.K ${ }^{1}$; Ogbuagu, U.R ${ }^{2}$; Iyam, M.A ${ }^{3}$; Osuchukwu N. C ${ }^{4}$, Eko, J.E \\ Achoakawa, C.E ${ }^{4}$;Osonwa, R.H ${ }^{5}{ }^{\text {Asuquo, O.D }}{ }^{4}$; Onovo, A.A. ${ }^{4}$ \\ ${ }^{1,}$ Department of Sociology, University of Calabar, \\ ${ }^{2}$ Department of Economics, University of Calabar, \\ ${ }^{3}$ Department of Vocational Education, University of Calabar, \\ ${ }^{4}$ Department of Public Health, University of Calabar, \\ ${ }^{5}$ Department of Foundation, Guidance \& Counseling, University of Calabar
}

\begin{abstract}
This study was carried out to find out the knowledge, attitude and risk perception of HIV/AIDS among Youths in Calabar, Nigeria. The simple random sampling techniques was used to select five hundred respondents used as the sample for the study. Secondary data were obtained from relevant documents and it provided the background information on HIV/AIDS and other related issues. Primary data constituted the inputs used for the empirical analysis of the study, obtained through the administration of questionnaire. Data collected were analyzed using frequency tables and percentages. The findings show that the awareness of HIV/ AIDS is high, but the risky sexual habits remains unimaginably high. It is recommended that other approaches of sensitization apart from the television medium should be exploited, and religious bodies fully involved in HIV/AIDS activities.
\end{abstract}

Keywords: Hiv/Aids, Attitudes, Risk, Perception, Youths.

\section{Introduction}

The first case of HIV and AIDS in Nigeria was identified in 1986. Since then, the HIV prevalence has grown exponentially. Global epidemic evidence of 2005 survey, shows that all states in Nigeria have a prevalence rate of 5\%, including the Federal Capital Territory. The sentinel surveillance system has indicated HIV prevalence of $1.8 \%$ in 1991 and $4.6 \%$ in 2008, which shows a remarkable increase over the years. At the end of 2007, there were an estimated 2.6 million people infected with HIV in Nigeria and approximately 170,000 people died from AIDS in the same year.( UNAIDS,2008). In recent years, life expectancy in Nigeria has declined partially as a result of the effects of HIV and AIDS. In 1991, the average life expectancy was 53.8 years for women and 52.6 years for men (UNFPA,2005). The 2007 estimate had fallen to 50years for women and 48years for men (WHO,2009).

The Human Immune-Deficiency Virus (HIV) on entering the body attack particularly the white blood cells in the blood called CD4 cells. These are the blood cells that fight to protect the body against infection. HIV can be transmitted through four major ways namely: transmission through blood, transmission through sexual intercourse, transmission through injection route and mother-to-child transmission known as vertical transmission (World Bank, 2001). HIV/AIDS burdens not only on the individuals affected but also on their families and the country at large.

Gottlieb (1999) listed effects of HIV/AIDS on the individuals to include illness and suffering, shortened life span, loss of work and income, death of family members associated with grief, poverty and despair, stigma and discrimination, deteriorating child health survival as well as weakened integrity and support structure of the family unit.

In Nigeria, the recent HIV prevalence rate among adults aged 15-49 is 3.9 per cent . Nigeria has the third-largest number of people living with HIV. The HIV epidemic in Nigeria is complex and varies widely by region. In some states, the epidemic is more concentrated and driven by high-risk behaviour, while other states have more generalized epidemics that are sustained primarily by multiple sexual partnerships in the general population. Youths and young adults are particularly vulnerable to HIV, with young women at a higher risk than young men.

An estimated 5.1\% - 54\% of the Nigeria population has been infected with HIV/AIDS by 1999 and by 2006, 6.1 million of 140 million population is living with HIV/AIDS. The situation becomes worrisome as the number of people with the disease is expected to grow significantly by the end of 2010 . It was in 2000 that the Nigerian government recognized HIV/AIDS as a major health problem.

Cross River State was among the first states that an emergency was declared of HIV/AIDS. With a population of 3.1 million, 56,350 persons currently live with HIV/AIDS virus Simpson (2008). 


\section{Objectives Of The Study}

The major objective of this study is to evaluate the level of knowledge, attitude and risk perception of Hiv/Aids among youths in Calabar, Cross River State.

\section{Literature Review}

Ukpong (2006) noted that a greater uninformed population on HIV/AIDS reside in rural communities hence emphasis is on rural communities. By virtue of their distant location from urban towns, undulating topography, poor access roads, rural communities are disadvantaged and often denied health information and health services, this situation has remained so over the years as it is only recently that rural communities are beginning to feel the presence of government by way of provision of good access roads, electricity, pipe borne water and provision of health centres staffed with qualified health personnel.

Numerous efforts have been made to fight the spread of HIV/AIDS. For instance, at the Federal level, health education programmes for the prevention/control of spread of HIV/AIDS are established and coordinated by the National Agency for control of AIDS (NACA), at the state level by the State Agency for Control of AIDS (SACA) and at the Local Government level by the Local Agency for Control of AIDS (LACA), (Odutolu, 2006). A lot of non-government organizations and agencies with a focus on community health education on prevention/control of spread of HIV/AIDS in rural communities have been established in recent times and enormous success has been recorded in this regard (UNAIDS, 2008). Activities embarked by government and non-governmental organizations include:

1. Sensitization

2. Community mobilization and participation

3. HIV/AIDS counseling and testing programme

Through the sensitization programme, individuals are equipped with confidence to be able to negotiate sex and assess the risks of any type of sexual activity (Ukpong, 2006). Individuals also know how to reduce the risk of infection by accepting abstinence, delaying sexual activity, using condoms and reducing their number of partners (Martinez, 2007). Sensitization also encourages people to judiciously use the health services provided as well as make their own choices and decisions on health matters (Oluh, 2007).

Community participation programme on the other hand is instrumental in increasing awareness about HIV transmission within the community, producing attitude change among individuals, helps increase condom use, provides a change in behaviour among high risk groups, empower community members to become peer educators, establishes trust between the care-giver (researchers) and the researched and also enhances better community penetration (Lau and Muula, 2004; Busza and Schunter, 2000; Elezuo, 2001 and Priest, 2002).

The HIV counseling and testing (HCT) programme is of huge benefits to the clients, couples and community at large. It empowers clients to make informed decision to know their HIV status. It empowers the uninfected person to protect himself or herself from becoming infected with HIV and also offers infected persons opportunity for treatment of HIV and associated illness (Ofut, 2007).

Support groups have in no small measure helped in the prevention/control of HIV/AIDS by equipping her members with current information on HIV/AIDS (how to stay uninfected and how to live positively if infected), peer counseling to areas further away from the location of support groups (Amon, 2009; Alokpa, 2009; and Mba, 2009). The implementing partners progrmame makes home-based care and education available to people living with HIV/AIDS (UNAIDS, 2008). Through this programme, other health problems peculiar to individual families as well as high risk behaviour are detected and family members are educated accordingly. By so doing, health problems that would have graduated to complex situations and behaviours which would have exposed uninfected family members to HIV infection are "nipped-in-the-bud" (Williams, 2008 and Simpson, 2008).

Monitoring and evaluation of HCT programme also prevents and controls the spread of HIV infection by training and retraining counselors and testers and making available, up-to-date records on the prevalence of HIV infection in the local, state and national levels (Onah, 2009; Armon, 2009; and SACA, 2009). Through the monitoring and evaluation of HCT programme, lapses which hinder remarkable success in the prevention/control of spread of HIV infection are detected and "corresponding intervention" employed. A typical situation in this regard requiring resensitization happened in 2007, in Ikom Local Government Area of Cross River State where commercial sex workers objected the use of condoms because according to them, their customers who must use condoms refused to pay commensurate fees to the services rendered by these sex workers; their excuse was the sex with condoms was not pleasurable (Okoi, 2007).

Monitoring and evaluation of HCT is a very rewarding programme in terms of identifying people and places that require extra attention if effective prevention/control of spread of HIV infection must be achieved.

Ukpong (2006) noted that people have different perceptions on health issues; their perceptions go a long way to determining their health seeking behaviour and attitude to treatment. According to him, the value 
placed on a service is dependent on the way the issue is perceived, evaluated and acted upon by a person. Perception on an issue is influenced by different factors for different people, nevertheless, behaviour performed towards an issue per time is an indication of how an individual has perceived/evaluated the matter (Oluh, 2007).

Inspite of information, services on HIV/AIDS available in both urban and rural communities, the perception of community members on the established programmes determines to a large extent attitude to information, attitude to care-givers, utilization of services and health status of community members (Oluh, 2007).

\section{Theoretical Framework}

Several theories of health on attitude, belief and behavioral change have been propounded. These are, Protection Motivational Theory, Cognitive-Social Health Information- Processing model, the Health Belief model, Theory of Planned Behavior and Social Learning Theory. Of all these theories, the Health Belief Model is considered appropriate for use in this study. This model is founded on the work of Kurt Lewin, modified by Becker(1986). According to them, the life space in which individuals live is composed of regions, some having a negative valence(one would seek to avoid), some a positive valence( one would seek to approach), and some a neutral valence ( one would neither seek to approach nor avoid).

The aim of the model was to determine why some person's who are illness-free take actions to avoid illness, whereas other fail to take protective actions, Gorin and Arnold (2006). The model is capable of predicting the conditions under which people would engage in simple preventive behaviors. The Health Belief model suggests that before an individual takes action, he or she must decide that the behavior, whether it be smoking, eating fatty foods, or engaging in unprotected sexual activity, creates a serious health problem; that he or she is personally susceptible to this health harm; and that moderating or stopping the behavior will be beneficial. The perceived barriers to undertaking a behavior are considered most salient to heath promotive efforts (Janz and Becker, 1984).

A person's perceived susceptibility to disease and perceived severity of harm are based to a great extent on that person's knowledge of the disease and its potential outcome. Although the combination of perceived susceptibility to harm and severity of harm provides the force for action and the perception of high benefits and low barriers provides a course of action that starts the process of change.

This theory explains the continuous prevalence of Hiv/Aids. Many people do not believe that Hiv/Aids is real. Their perceived susceptibility is low. This is made worse because of the inter-play of cultural influences in the definition of disease and illness. In African traditional setting, it is believed that illness is as a result of evil machination of witches, sorcerers, deities and ancestral causes, Ihejiamaizu (2002). To stay alive for them means the continuous appeasement of the gods who protect from all evils. However over the years modernization and Christianity have played vital role to change this belief.

\section{Statement Of Problem}

HIV/AIDS has been identified as the worst health crisis the world is facing today. It has become a major public health issue worldwide especially among developing nations, complicated by socio-economic factors such as ignorance, unemployment, stigmatization and poor nutrition Noulen (2007).

HIV/AIDS has ravaged the lives of individuals and families and consequently reduced the population of countries in hundreds of thousands and millions across the globe (Gottlieb, 1999). It has a high global burden of poor economic development, overwhelmed health care systems, decreasing life expectancy, deteriorating child survival rates and increasing number of orphans (Gottlieb, 1999). The devastating effects of HIV/AIDS calls for dedicated and sustained acceleration of prevention strategies against the transmission of the virus since everybody is at risk of "either being infected or affected". On this note, International Agencies, government and non-governmental organizations have embarked on a lot of activities ranging from funding establishment of sensitization programme (through the media, journals, conferences and seminars on HIV/AIDS), community participation programme, HIV counseling and testing programme, support groups programme, implementing partners, programme as well as monitoring and evaluation of HIV counseling and testing programme. Effort has also been made in the area of provision of Anti-Retroviral drugs for victims of HIV/AIDS and recently provision of good access roads, establishment of health facilities, staffed with qualified personnel in rural areas particularly to facilitate service delivery with regards to prevention/control of spread of HIV/AIDS.

Inspite of the above effort by the government, non-governmental organization and foreign agencies to create awareness on the prevention/control of spread of HIV/AIDS so that people can make informed decision to stay free from HIV infection, remarkable success has not been achieved in this direction especially in rural communities. It has been observed with dismay that people in rural communities live recklessly and indulge in risky behaviours capable of exposing them to HIV infection, for an example the practice of polygamy, unfaithfulness among married partners, indiscriminate sexual exploit by youths, sharing of sharp objects, smoking, alcoholism, use of hard drugs and so on. This has resulted in a high prevalence of victims of 
HIV/AIDS in rural communities, illnesses and sufferings, shortened life span, loss of work and income, death of family members and associated grief, poverty and despair, stigma and discrimination, deteriorating child health survival, low level of education with high illiteracy rate and so on.

\section{Methodology}

This study was carried out in Calabar, Cross River State. Simple random sampling technique was used to select five hundred respondents used as the sample for the study. Primary and secondary data were utilized for the study. Secondary data was obtained from relevant documents and it provides background information on HIV/AIDS and other related issues. Primary data, on the other hand constitutes the bulk of inputs used on the empirical analysis of the study. It is obtained through the use of questionnaire which contained a number of questions on knowledge, attitude and risk perceptions about HIV/AIDS. Data collected were analyzed using simple frequency tables and percentages.

\section{Data Analysis}

The result in Table 1 shows that 265 males representing 53\% were used with females, 235 representing 47\%. Similarly, the age bracket 15-19years had 67 (13.4\%), 20-24years, 166 (33.2\%), 25-29years, 184 (36.8\%), 30-34years, $33(6.6 \%)$ and 30years and above had 50 (10\%). I 450 representing 90\% are single, $17(3.4 \%)$ are cohabiting, and $33(6.4 \%)$ are married. On occupation, while a total of 167 representing $33.4 \%$ engage in private service work, $83(16.6 \%)$ are civil servants, $33(6.6 \%)$ are Bankers, $17(3.4 \%)$ are Traders, $17(3.4 \%)$ are NGO workers, $33(6.6 \%)$ are students, $83(16.6 \%)$ are unemployed, $17(3.4 \%)$ are self-employed, $17(3.4 \%)$ engage in sports and $33(6.6 \%)$ represents missing values. Educationally, a total of 78 representing $15.6 \%$ have no formal education, $128(25.6 \%)$ have primary education, another 245 (49\%) have secondary education, while $49(9.8 \%)$ possess tertiary education.

About $74.0 \%$ of the respondents had a high level of HIV and AIDS knowledge and a good attitude towards sex. $80 \%$ of the respondents reported having had sex and first initiation of sexual act at mean age of 18 . In the last 12 months, 805 of the respondents reported having had sexual intercourse with at least 19 different people. $67.9 \%$ of the respondents reported using condom when having sex. Respondents with high level of education (Tertiary) responded $64.3 \%$ correctly to questions such as, engaging in risky sexual behaviour increases my chances of getting infected with HIV, while $35.7 \%$ illiterates responded to this question correctly. Among those who had heard of HIV/AIDS, 87.0\% perceived serious threat of AIDS to the human health in near future. Mass communication was a source of information on HIV/AIDS among $87.0 \%$ respondent. Television being the most common source of information (73.6\%).

TABLE 1: Showing demographic characteristics of respondents

\begin{tabular}{|c|c|c|c|}
\hline $\mathbf{S} / \mathbf{N}$ & Item & Frequency & Percentage \\
\hline \multirow[t]{4}{*}{1.} & Sex: & & \\
\hline & Male & 265 & 53 \\
\hline & Female & 235 & 47 \\
\hline & Total & 500 & 100 \\
\hline \multirow[t]{7}{*}{2.} & Age: & & \\
\hline & 15-19years & 67 & 13.4 \\
\hline & 20-24years & 166 & 33.2 \\
\hline & 25-29years & 184 & 36.8 \\
\hline & 30-34years & 33 & 6.6 \\
\hline & $35 y e a r s$ and above & 50 & 10 \\
\hline & Total & 500 & 100 \\
\hline \multirow[t]{5}{*}{3.} & Marital status: & & \\
\hline & Single & 450 & 90 \\
\hline & Cohabiting & 17 & 3.4 \\
\hline & Married & 33 & 6.6 \\
\hline & Total & 500 & 100 \\
\hline \multirow[t]{6}{*}{4.} & Education: & & \\
\hline & No formal education & 78 & 15.6 \\
\hline & Primary & 128 & 25.6 \\
\hline & Secondary & 245 & $49 \%$ \\
\hline & Tertiary & 49 & 9.8 \\
\hline & Total & 500 & 100 \\
\hline 5 & Occupation: & & \\
\hline
\end{tabular}


Knowledge, Attitude And Risk Perception Of Hiv/Aids Among Youths In Calabar, Cross River State,

\begin{tabular}{|l|l|l|l|}
\hline & Civil servant & 83 & 16.6 \\
\hline & Private service work & 167 & 33.4 \\
\hline & Banking & 33 & 6.6 \\
\hline Trading & 17 & 3.4 \\
\hline & Sport & 17 & 3.4 \\
\hline & Development work & 17 & 3.4 \\
\hline & Student & 33 & 6.6 \\
\hline & Unemployed & 83 & 16.6 \\
\hline & Self employed & 17 & 13.4 \\
\hline & No response & 33 & 6.6 \\
\hline & Total & $\mathbf{5 0 0}$ & $\mathbf{1 0 0}$ \\
\hline
\end{tabular}

\section{Source: Fieldwork}

TABLE 2: $\quad$ Level of knowledge of HIV/AIDS

\begin{tabular}{|l|l|l|l|}
\hline S/N & \multicolumn{1}{|c|}{ Item } & $\begin{array}{c}\text { Percentage } \\
\text { Yes (\%) }\end{array}$ & \multicolumn{1}{|c|}{$\begin{array}{c}\text { Response } \\
\text { No (\%) }\end{array}$} \\
\hline 1. & Do you believe HIV/AIDS is real in Cross River State? & 87.3 & 12.7 \\
\hline 2. & Do you know AIDS kills? & 83.5 & 16.5 \\
\hline 3. & $\begin{array}{l}\text { Can someone already infected with HIV still look } \\
\text { healthy? }\end{array}$ & 65.4 & 34.6 \\
\hline 4. & Do you know HIV/AIDS is preventable? & 64.6 & 35.5 \\
\hline 5. & Do you know HIV/AIDS is curable? & 80.4 & 19.6 \\
\hline 6. & Can use of condom prevent HIV/AIDS? 68.2 & 31.8 \\
\hline 7. & $\begin{array}{l}\text { Can people protect themselves from HIV/AIDS by } \\
\text { abstaining from sex? }\end{array}$ & 58.4 \\
\hline 8. & $\begin{array}{l}\text { Do you believe prayer is the way to prevent and cure } \\
\text { HIV/AIDS? }\end{array}$ & 51.5 & 48.5 \\
\hline
\end{tabular}

\section{Source: Fieldwork}

TABLE 3: $\quad$ Mode of Transmission

\begin{tabular}{|l|l|l|l|}
\hline S/N & \multicolumn{1}{|c|}{ Item } & Frequency & Percentage \\
\hline i. & Can HIV be passed from one person to another? & & \\
\hline & Yes & 483 & 96.6 \\
\hline & No & 17 & 3.4 \\
\hline & Total & $\mathbf{5 0 0}$ & $\mathbf{1 0 0}$ \\
\hline ii. & Sexual Intercourse: & & \\
\hline & Yes & 500 & 100 \\
\hline & No & 0 & 0 \\
\hline & Total & $\mathbf{5 0 0}$ & $\mathbf{1 0 0}$ \\
\hline iii. & Blood transfusion: & & \\
\hline & Yes & 412 & \\
\hline & No & 88 & \\
\hline & Total & $\mathbf{5 0 0}$ & \\
\hline iv. & Infected mother to unborn child: & & \\
\hline & Yes & 400 & 80 \\
\hline & No & 100 & 20 \\
\hline & Total & $\mathbf{5 0 0}$ & $\mathbf{1 0 0}$ \\
\hline v. & Sharing sharp objects like razor/needles: & & \\
\hline & Yes & 410 & \\
\hline & No & 90 & \\
\hline & Total & $\mathbf{5 0 0}$ & \\
\hline vi. & Mosquito bites: & & \\
\hline & Yes & 67 & 13.4 \\
\hline & No & 417 & 83.4 \\
\hline & $\ldots \ldots \ldots \ldots \ldots \ldots \ldots \ldots . \ldots \ldots y s t e m$ & 16 & 3.2 \\
\hline & Total & $\mathbf{5 0 0}$ & $\mathbf{1 0 0}$ \\
\hline vii. & Witchcraft: & & \\
\hline
\end{tabular}


Knowledge, Attitude And Risk Perception Of Hiv/Aids Among Youths In Calabar, Cross River State,

\begin{tabular}{|c|c|c|c|}
\hline & Yes & 150 & 30 \\
\hline & No & 350 & 70 \\
\hline & Total & 500 & 100 \\
\hline \multirow[t]{4}{*}{ viii. } & Kissing: & & \\
\hline & Yes & 133 & 6 \\
\hline & No & 367 & 73.4 \\
\hline & Total & 500 & 100 \\
\hline \multirow[t]{4}{*}{ ix. } & Hugging: & & \\
\hline & Yes & 0 & 0 \\
\hline & No & 500 & 100 \\
\hline & Total & 500 & 100 \\
\hline \multirow[t]{4}{*}{ x. } & Sharing food with someone infected: & & \\
\hline & Yes & 0 & 0 \\
\hline & No & 500 & 100 \\
\hline & Total & 500 & 100 \\
\hline \multirow[t]{4}{*}{ xi. } & Do you use condom during sex? & & \\
\hline & Yes & 340 & 67,9 \\
\hline & No & 160 & 32.1 \\
\hline & Total & 500 & 100 \\
\hline \multirow[t]{4}{*}{ xii. } & Abstaining from sex: & & \\
\hline & Yes & 345 & 69.0 \\
\hline & No & 155 & 31.0 \\
\hline & Total & 500 & 100 \\
\hline \multirow[t]{4}{*}{ xii. } & $\begin{array}{l}\text { Avoiding sex with people who have many sexual } \\
\text { partners: }\end{array}$ & & \\
\hline & Yes & 375 & 75.0 \\
\hline & No & 125 & 25.0 \\
\hline & Total & 500 & 100 \\
\hline
\end{tabular}

\section{Source: Fieldwork}

TABLE 4: $\quad$ Risky behaviours and perception

\begin{tabular}{|l|l|l|l|}
\hline S/N & \multicolumn{1}{|c|}{ Item } & Frequency & Percentage \\
\hline i. & Willing to do HIV test & & \\
\hline & Yes & 275 & 55.0 \\
\hline & No & 235 & 45.0 \\
\hline & Total & $\mathbf{5 0 0}$ & $\mathbf{1 0 0}$ \\
\hline ii. & AIDS is a threat to human health & & \\
\hline & Yes & 433 & 86.6 \\
\hline & No & 67 & 13.4 \\
\hline & Total & $\mathbf{5 0 0}$ & $\mathbf{1 0 0}$ \\
\hline iii. & Infected by having sex with multiple partners & & \\
\hline & Yes & 350 & 70.0 \\
\hline & No & 150 & 30.0 \\
\hline & Total & $\mathbf{5 0 0}$ & \\
\hline iv. & Willing to share meal with infected person & & \\
\hline & Yes & 350 & 70.0 \\
\hline & No & 150 & 30.0 \\
\hline & Total & $\mathbf{5 0 0}$ & $\mathbf{1 0 0}$ \\
\hline v. & Ever tested for HIV & & \\
\hline & Yes & 150 & 30.0 \\
\hline & No & 350 & 70.0 \\
\hline & Total & $\mathbf{5 0 0}$ & $\mathbf{1 0 0}$ \\
\hline vi. & Ever had sex & & \\
\hline & Yes & 400 & 80 \\
\hline & No & 100 & 20 \\
\hline & Total & $\mathbf{5 0 0}$ & $\mathbf{1 0 0}$ \\
\hline
\end{tabular}

Source: Fieldwork 


\section{Discussion Of Findings}

The distribution of the respondents shows that majority of them fall in the age group 25-29 (36.8\%). This age group is sexually active and more vulnerable population. This is in line with the findings of Fultz (2004) who showed that HIV/AIDS in Nigeria is highest among young people between 25-29years. Majority of the respondents are single, $90 \%$ of the total sample. This is not surprising because Calabar town is accommodating four institutions of higher learning. Majority of the inhabitants are students who are unmarried. This group represents the $49 \%$ with secondary education.

Large number of the sampled youths are aware of HIV/AIDS and have accurate knowledge of its mode of transmission (see table 3). The respondents identified "sexual intercourse" as a major means of contracting HIV/AIDS, and uses condom as a means of protection. This is in contrast with the work of Ewuzie (2005) which showed a below average use of condom among use. It means the sensitization of the use of condom has impacted on the youths.

A mean age of 18 was observed as the first initiation of sexual act. This supports the work of Akuto (2004), which showed that majority of age at first sex experience ranges from 18-25years.

HIV/AIDS infection is attributed to witchcraft. 30\% of the respondents are of this opinion. Bruyn (2002) noted that in Nigeria, there is no pathological disease condition which does not have a spiritual connection, that every disease is a function of a bewitched origin before its manifestation. Voluntary test for HIV is still poor as evidenced by $70 \%$ of the respondents who indicated never tested for HIV. This buttress the point that perception of HIV as a threat to life is still poor among the youths. Ukpong (2006) had noted that people have different perceptions on health issues, their perceptions go a long way to determining their health seeking behaviour and attitude to treatment. $80.4 \%$ of the respondents believe that HIV/AIDS like other diseases is curable(table 2). This belief is heightened by the claims of the spiritual churches as to "casting out the demons" of HIV/AIDS, and their clients have often testified being cured, however this is subject to scientific verifications, . although majority believe that the churches can cure it(table 2).

The respondents indicated ever willing to do Hiv test. They acknowledged Aids as a threat to human life and believed that multiple partnership increases the risk of contacting Hiv/Aids(table 4). Majority of the respondents indicated that they have never done Hiv test even though they indulge in sexual activities

\section{Conclusion And Recommendations}

Based on the findings of this study, it could be concluded that the awareness and knowledge of HIV/AIDS is high in Calabar. Despite this awareness, the attitude of the youths towards HIV/AIDS epidemic is not encouraging. The risk of contracting the disease is still high, demonstrated by the risky sexual habits of the youths. As has been observed, television remains the most common source of information on HIV/AIDS. As observed by Mempho (2003), there are a few other innovative approaches in HIV/AIDS sensitization and they include music and drama as a means of projecting health messages. The state agency in charge of HIV/AIDS can sponsor the drama and music of HIV/AIDS activities. The surge in the movie industry and the drive towards the patronage of home video by the masses will go a long way in sensitizing people on HIV/AIDS.

Community participation is important in HIV/AIDS prevention. This is because the people who form a community are the most direct link to making a difference within that community. Therefore, any public health research that aims to be successful cannot afford to overlook this resource when planning strategies (Lau and Muula, 2004). It is recommended therefore that the community members should be involved in HIV/AIDS activities.

\section{References}

[1] United Nations AIDS (UNAIDS, 2008). Global HIV/AIDS epidemic. 2008 Update Report.

[2] United Nations Population Fund(UNFPA).2005, State of the World Population 2005. The promise of equality, gender equity, reproductive health and the millennium Development Goals. New York.

[3] World Health Organization(WHO).2009. World Health Status 2009. Geneva.

[4] World Bank (2001). World Development Report. Global Update 2001. Online

[5] Gottlieb, M. (1999). The Monster called HIV/AIDS. Journal of AIDS in Africa. 1 (1) $26-28$.

[6] Simpson, B. (2008). World Class Research on "Slim Disease". Journal of Public Health. $30(12) 54-63$.

[6] Ukpong, P. J. (2006) Primary Health Care in Nigeria: Prospects and failures. $1^{\text {st }}$ ed. Ikot Ekpene: Augustinno Printers

[7] Odutola, O. (2006) AIDS in Nigeria: A nation on the threshold. Journal of Medicine and Social Sciences.

[8] UNAIDS (Joint United Nation Programme on HIV/AIDS).2008.2008 report on the global AIDS epidemic Geneva: UNAIDS.

[9] Martinez, D. (2007) Understanding AIDS: Etiology, Diagnosis, Treatment and Prevention. Position Paper, Evidence - Based Care of HIV/AIDS Patients Workshop.

[10] Oluh, C. (2007) Comprehensive Primary Health Care for Nurses and Midwives. Enugu: Snap Press Ltd.

[11] Lau, C. and Muula, D. (2004). Infectious diseases and life saving assistance. Journal of Nursing. 2(1) $56-60$.

[12] Ofut, W. (2007). The magic in HIV/AIDS support groups. Position paper: Workshop on Enhanced programmes for longevity of HIV/AIDS victims.

[13] Armon, A. E. (2009). Position Paper: HIV Counseling and Testing. Abuja: Training of Trainer Workshop . Priest, Y. (2002). Impact of HIV/AIDS Infection on family stability among couples. Research Project. Ogoja: School of Nursing.

[14] William, I. (2008). HIV Infection and Socio-economic status in developing countries. Journal of Health Care. 7(3) 8 - 14. 
[15] Okoi, E. (2008). Monitoring and Evaluation of HCT and Prompt Detection of Lapses/Wrong Practices at HIV counseling/Testing Sites Towards Ensuring Quality Service Delivery. ACTIONAIDS Cross River State: Research Project.

[16] Busza, L and Shunter, A. (2001). Belief about HIV/AIDS and Management Strategies. Journal of Public Health. 2(4) $19-22$.

[17] Becker, M (1986): The Tyranny of Health Promotion, Public Health Review, 14(15-23).

[18] Elezuo, T. T. (2001). The role of psychotherapy in the Emotional health of HIV/AIDS victims. Research project. Calabar: College of Health Technology.

[19] Gorin, S.S and Arnold, J (2006):Health Promotion in Practice, San Francisco CA, Jossey- Bass imprint.

[20] Janz, N.K and Becker, M. H(1984): The Health Belief Model. A Decade later, Health Education Quarterly,11,1-47.

[21] Alokpa, M. (2009). Care and Management of AIDS Victims. Unpublished Trainers Guide. Enugu: AIDS Action.

[22] Mempho, N. (2003). Stress Therapy for HIV Victims. $1^{\text {st }}$ ed. Igoli-Ogoja: M \& I Printers.

[23] Mba, B. (2009). Promoting Positive Living with HIV/AIDS. Unpublished lecture material. Calabar: School of Nursing.

[24] Noulen, S. (2007) 28 stories of AIDS in Africa. Porto Bello Books 106.

[25] Ihejiamaizu, E. C(2002): Issues in Population Policy and Health Care Administration; Calabar, African Scholars' Publishing Company.

[26] Fultz, P. N. (2004). HIV-1 Superinfections: Omens for Vaccine Efficacy. Journal of AIDS Care. 1 (18).

[27] Ewuzie, M. A. (2005). Fundamentals of Communicable and Non-communicable diseases. $1^{\text {st }}$ ed. Owerri: Chitolynn Printers and Publishers.

[29] Akuto, E. E. (2004). Private Health Care Provider Analysis Studies. End of Project Report. Nigerian Journal of Health Care. 2(8) $14-21$

[30] Bruyn, M. D. (2002). Women and AIDS in developing countries. Journal of Social Science and Medicine. 34 (3) 249 - 26. 